\title{
Influence of submarine morphology on bottom water flow across the western Ross Sea continental margin
}

\author{
F. J. Davey ${ }^{1}$ and S. S. Jacobs ${ }^{2}$ \\ ${ }^{1}$ GNS-Science, PO Box 30368, Lower Hutt, New Zealand, ph +64 4 5704807, f.davey@gns.cri.nz \\ ${ }^{2}$ Lamont-Doherty Earth Observatory, Palisades, NY 10964, USA, sjacobs@ldeo.columbia.edu
}

Summary Multibeam sonar bathymetry documents a lack of significant channels crossing outer continental shelf and slope of the western Ross Sea. This indicates that movement of bottom water across the shelf break into the deep ocean in this area is mainly by laminar or sheet flow. Subtle, $\sim 20 \mathrm{~m}$ deep and up to $1000 \mathrm{~m}$ wide channels extend down the continental slope, into tributary drainage patterns on the upper rise, and then major erosional submarine canyons. These down-slope channels may have been formed by episodic pulses of rapid down slope water flow, some recorded on bottom current meters, or by sub-ice melt water erosion from an icesheet grounded at the margin. Narrow, mostly linear furrows on the continental shelf thought to be caused by iceberg scouring are randomly oriented, have widths generally less than $400 \mathrm{~m}$ and depths less than 30m, and extend to water depths in excess of $600 \mathrm{~m}$.

Citation: Davey, F. J. and S. S. Jacobs (2007), Influence of submarine morphology on bottom water flow across the western Ross Sea continental margin, in Antarctica: A Keystone in a Changing World - Online Proceedings of the 10th ISAES, edited by A. K. Cooper and C. R. Raymond et al., USGS Open-File Report 2007-1047, Short Research Paper 067, 5 p.; doi:10.3133/of2007-1047.srp067

\section{Introduction}

Multibeam sonar bathymetry over the western Ross Sea continental margin can provide insight into the erosional processes that form the morphology of the seafloor of the region. In this area salty, dense and cold High Salinity Shelf Water (HSSW) mixes with cold, fresh Antarctic Surface Water and warm, salty Circumpolar Deep Water at the Antarctic Slope Front to form Antarctic Bottom Water that sinks into the deeper parts of the Southern Ocean (Jacobs and Giulivi, 1999). Whitworth and Orsi (2006) estimate that HSSW comprises about $17 \%$ of the Antarctic Bottom Water. The shelf and slope morphology will both influence and reflect this off-shelf flow (Dinniman et al., 2003). Bottom currents flowing along and across the continental margin are often depicted as requiring major channels that cut through the continental shelf break to facilitate transport into the deep ocean (e.g., Baines and Condie, 1998). The major morphological features of the Ross Sea and its northwest margin have been defined and discussed by several authors - e.g., Hayes and Davey (1975), Anderson (1999), Shipp et al. (1999), and Davey (2004). Many of the features can be related to iceberg scour, as also inferred elsewhere on the Antarctic margin (Lien, 1981; Barnes, 1987; Barnes and Lien, 1988; O'Brien et al., 1994), and grounded ice sheet bed features, like flutes and drumlins (Anderson, 1999; Shipp et al., 1999). We have compiled regional multibeam bathymetry for the continental shelf margin in the northwest Ross Sea in order to document this morphology in more detail. A central objective in our study is to additionally relate this new bathymetry to bottom current measurements in the same area (Gordon et al., 2004; Whitworth and Orsi, 2006) and to geological measurements (Shipp et al., 1999), inferring relationships between bottom water flow, iceberg movements, relict morphology from grounded ice and sediment flux at the shelf edge.

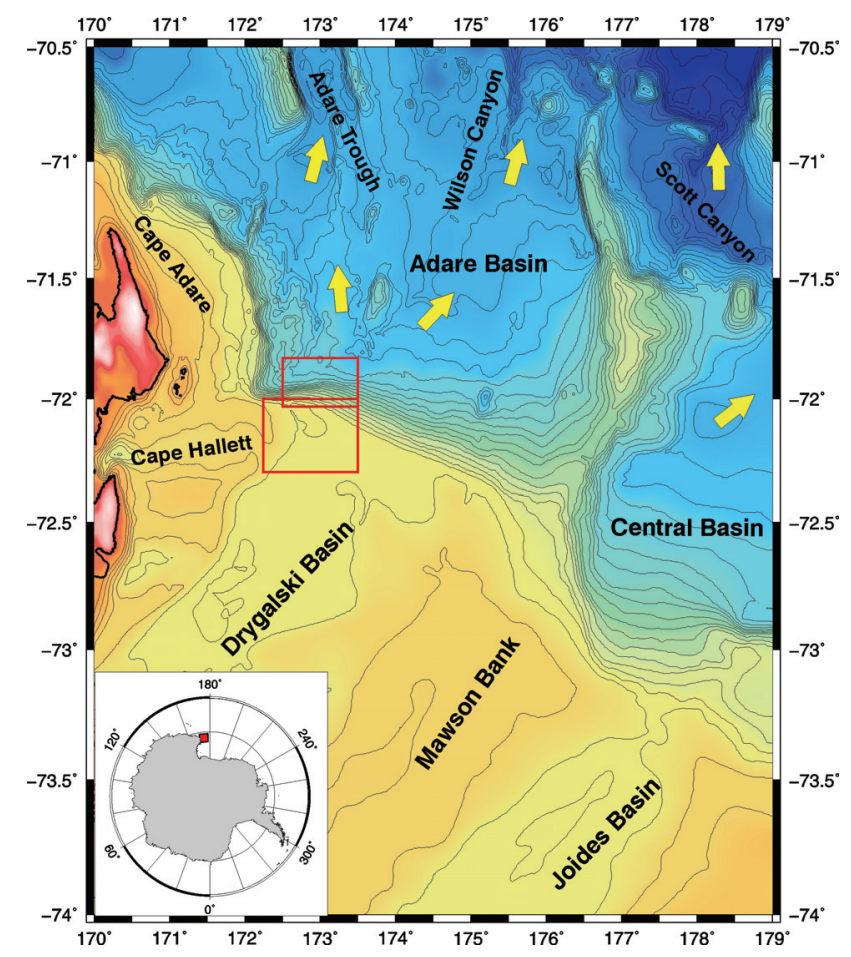

Figure 1. Bathymetry of the Western Ross Sea showing the major troughs with shelf-edge sills. Contours at 100 $\mathrm{m}$ intervals (after Davey, 2004). Yellow arrows - rise flow paths. Red lines delineate extent of maps in Figure 2 - lower box, and Figure 3 - upper box. Inset location (red box) of Figure 1 in Antarctica

\section{Morphology}

The morphology of the western Ross Sea continental shelf is characterised by major SSW-NNE-trending troughs - the Drygalski and Joides Basins that extend from beneath the Ross Ice Shelf to the continental shelf break (Davey, 2004). 
At the shelf break these troughs terminate in sills (possibly caused by proglacial till deltas of a pre LGM icesheet advanced to the shelf edge, e.g. Bart and Anderson (2000)) about $100 \mathrm{~m}$ shallower than the trough immediately up-stream toward the continent, and $300 \mathrm{~m}$ deeper than the adjacent banks. None of these troughs extend beyond the shallow sill to continue as canyons extending down the continental slope (Figure 1). They deepen to the south, reaching depths in excess of $1250 \mathrm{~m}$ near the Drygalski Ice Tongue and $2500 \mathrm{~m}$ where the David Glacier feeding that tongue crosses the grounding line (Rignot and Jacobs, 2002).

The sea floor of the western Ross Sea is characterised by a dense network of small ( $5-20 \mathrm{~m}$ deep, $80-400 \mathrm{~m}$ wide) channels or furrows (Fig. 2 - see also Shipp et al., 1999). One furrow, labelled A in Figure 2, has a width of $1200 \mathrm{~m}$ and is a double furrow. These furrows occur over a depth range of $350 \mathrm{~m}$ to $600 \mathrm{~m}$, and have linear and arcuate to circular tracks. Their maximum length is 15 $\mathrm{km}$, with the circular and arcuate furrows having diameters of up to $15 \mathrm{~km}$. Many furrows trend generally northeast to northwest reflecting the common direction of iceberg movements (Keys et al., 1990), but there is no dominant trend. Some major furrows stop (or start) abruptly, are aligned down the slope of the major banks into the troughs (west - east), and change trend sharply. Small scale mounds or banks occur immediately on the

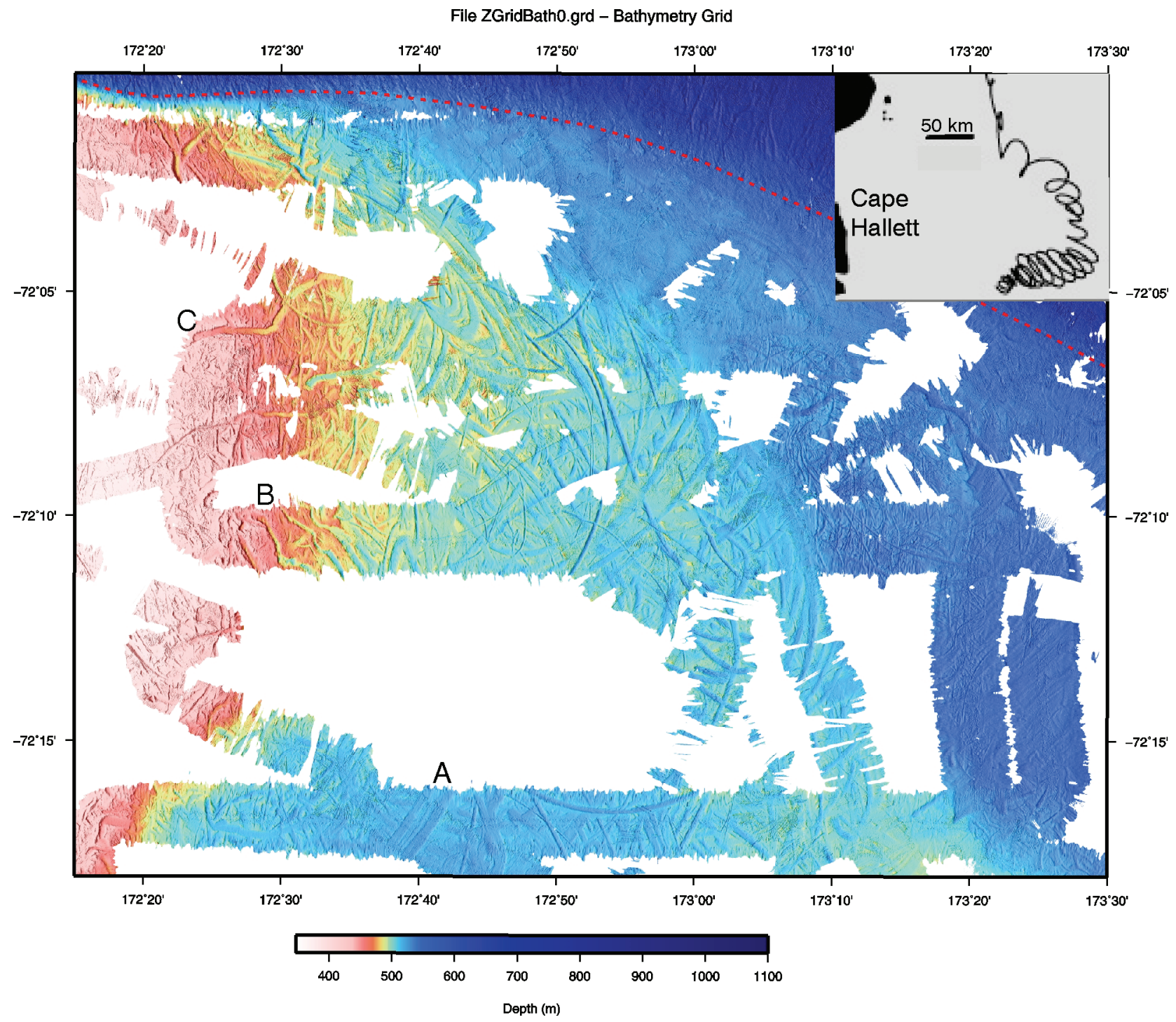

Figure 2. Detailed multibeam sonar bathymetry for the area shown by the lower red box in Figure 1. Depths are colour coded and the image illuminated from the west. A, B and C are channels referred to in text. Ross Sea shelf break - red dashed line. Inset GPS controlled track of iceberg movement through western Ross Sea (courtesy D. MacAyeal, 2007). The image covers the region from the Drygalski Basin sill to the shelf break. 
sides of some furrows. The furrows fade with increasing water depth north of the top of the trough sill, before the shelf break is reached at about $600 \mathrm{~m}$ depth.

On the upper continental slope, just below the shelf break, narrow, subdued gullies form and run into broad, shallow (10 - $40 \mathrm{~m}$ deep, 1 - $2 \mathrm{~km}$ wide) and sinuous channels that trend down slope (Fig. 3). At the base of slope, at about $1800 \mathrm{~m}$ depth, a network of channels develops, similar to terrestrial tributary drainage patterns, and coalesce into major canyons at depths of about 2200m (Fig. 4). These major channels for transfer of water to the deep ocean basin are the Scott Canyon in the east, the Wilson Canyon and the Adare Trough (Cande et al., 2000), a striking rift structure (Houtz and Davey, 1973), in the west. No submarine channels or canyons are observed west of the Adare Trough.

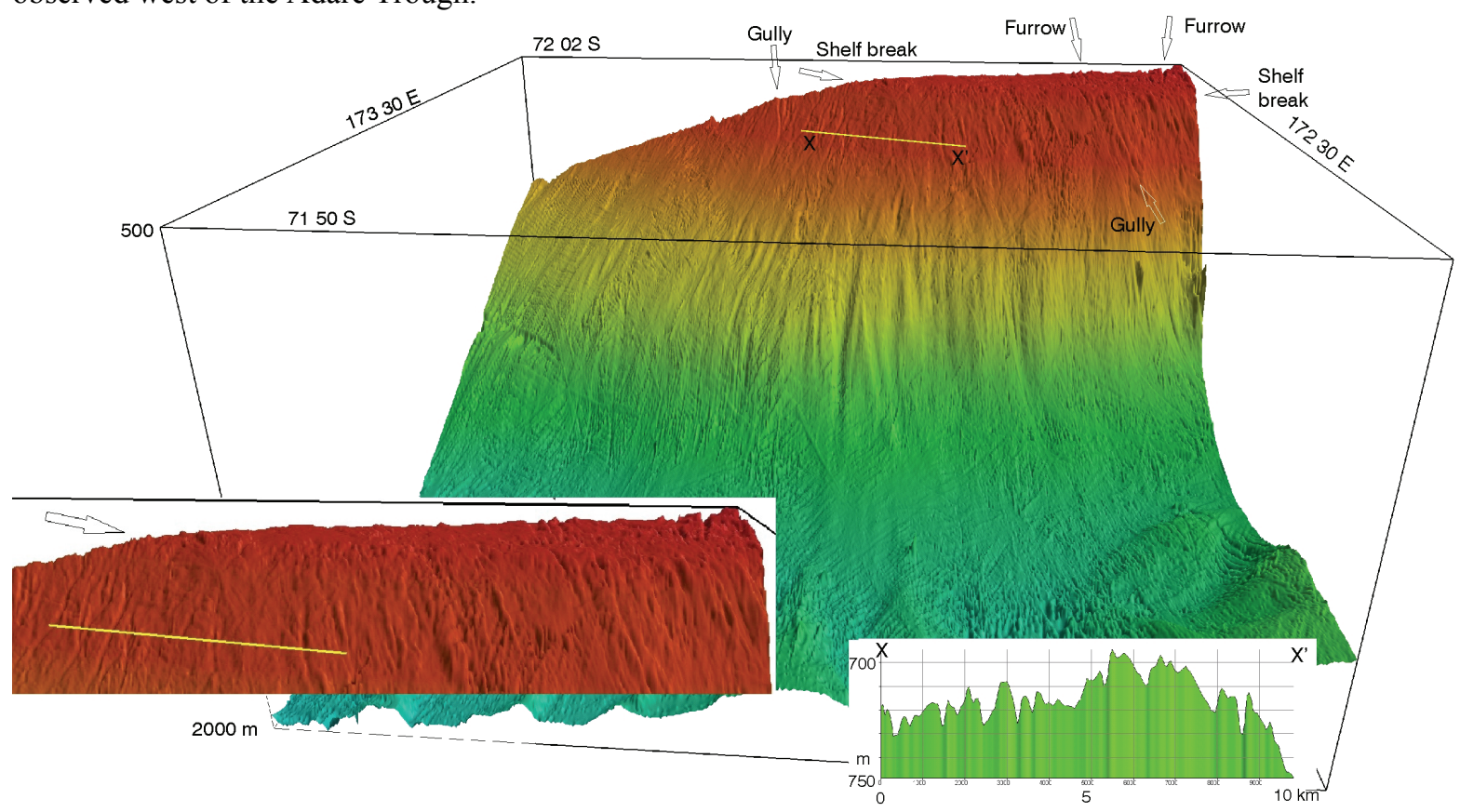

Figure 3. Detailed multibeam bathymetry image for the shelf break - continental slope area delineated by the upper red box in Figure 1, showing furrows, gullies and slope channels. Image is viewed from the north and illuminated from the north-west. The morphology along a $10 \mathrm{~km}$ profile, $\mathrm{X} \mathrm{X}^{\prime}$ (yellow line), is shown in the lower right inset. An enlargement of the shelf break region is shown in the lower left inset.

Shipp et al. (1999) divide the inferred ice scour channels or furrows they recorded over the Ross Sea into two groups. A linear type, largely on the trough flanks in the south and central Ross Sea they attribute to grounded ice sheet erosion during the Last Glacial Maximum (LGM). A group of more randomly oriented, more northerly furrows are attributed to scour by icebergs that calved off the grounded ice sheet. Our survey area lies north of the maximum extent of the grounded ice sheet during the LGM and the generally random direction of the furrows is consistent with the model of Shipp et al. (1999). The sweeping, arc-like iceberg trajectories implied by these scour features are consistent with the

\section{Discussion}

The major morphological troughs on the continental shelf are considered to be largely formed by grounded ice-sheet features, most probably ice-streams, during past advances of the continental ice sheet to the shelf edge (e.g., Houtz and Davey, 1973; Shipp et al., 1999). The sills at their seaward ends are likely to lead to recirculation of water below sill depth within the troughs. No major channels cross the shelf break. This suggests that most off-shelf flow near the sea floor does not incorporate the densest water in the troughs, and is not primarily focused into high-velocity plumes by the bathymetry, but may well be focused into laminar or sheet-like flows. 
a similar sub-glacial origin from a pre LGM ice sheet that grounded at the continental shelf margin. The sinuous furrows at $7209^{\prime}, 17230^{\prime} \mathrm{E}$ (B on Figure 2), and the eastwest flat bottom furrow about $400 \mathrm{~m}$ wide and $30 \mathrm{~m}$ deep at $7206^{\prime}$ south $17225 \mathrm{E}$ (C on Figure 2) that extends into deeper water where it turns north and fades, are two such examples.

Recent major icebergs (B15 and C19, both in excess of $120 \mathrm{~km}$ long) grounded in water depths of only about $280 \mathrm{~m}$. To explain the depth of inferred iceberg scours, up to $600 \mathrm{~m}$, recourse has often been made to lower sea levels at glacial maxima and to model studies that indicate rolling or tilting of icebergs could increase their drafts (Keys, 1990; O'Brien et al., 1994; Barnes and Lien, 1988). Shipp et al. (1999) note that the grounded ice sheet at the Last Glacial Maximum would have been marine based and calculate a minimum thickness of $635 \mathrm{~m}$ thick at the grounding line in the Drygalski Basin. Thick icebergs that calved from the margin could give rise to the deep scour furrows. The limited width of the furrows, 400 $\mathrm{m}$ with relatively sharp edges, however, is difficult to explain. The furrows fade on the north, ocean, side of the trough sills probably caused by "lift-off" of the icebergs (see upper right corner of Fig. 3 left inset), and do not continue across the shelf edge. The extensive region of scour channels will contribute to the bottom roughness and may contribute to the scale of the bottom boundary layers via turbulent mixing. More detailed work is needed to reveal the age of the iceberg furrows, their connections to modern vs. LGM iceberg drafts, sedimentation rates, sediment transport and the bottom benthos. Barnes and Lien (1988) noted that new scour channels occurred in the Weddell Sea over a period of three years, thus it is likely that a mixture of new and very old iceberg scour features are evident in the study area.

The continental slope of the western Ross Sea is steep in the west and gradually decreases in dip toward the east. The subdued gullies and broad, shallow sinuous channels trending down slope are features of the western part of the continental slope (Figure 3). The gullies are not continuous with the iceberg furrows (which fade away at the shelf break), and start at depths greater than reached by inferred iceberg scour. Their orientations are generally down slope to $\sim 30$ degrees west of down slope. Seismic data indicate little or no soft sediment cover in these channels. They have orientations that are less consistent with the general bottom flow, i.e., along the slope within 30 degrees of the bathymetry contours, than with present episodic pulses of rapid down slope flow of dense HSSW as noted by Gordon et al. (2004), or sediment loaded turbidity currents. Erosive activity would be expected to correlate positively with velocity, and measured current speeds near bottom often exceed $1 \mathrm{~m} / \mathrm{s}$ in the bottom boundary layer (Gordon et al., 2004; Whitworth and Orsi, 2006). The channels suggest this process of episodic catastrophic down slope flow may occur widely along the western part of the shelf edge. The seafloor sediments in this area are gravel lags and rippled sands (Anderson, 1999; Shipp et al., 1999) consistent with strong currents that have winnowed out lighter fractions. This could also help to explain the low turbidity in light transmission data on station profiles in the region. Alternatively, earlier sub-ice sediment loaded, melt water flow from under a grounded ice sheet that reached the continental margin may be the cause, as proposed by Dowdeswell et al. (2006) for similar gullies at Pine Island Bay. In which case the gullies would be older than the LGM as this did not reach the continental edge in western Ross Sea (Shipp et al., 1999).

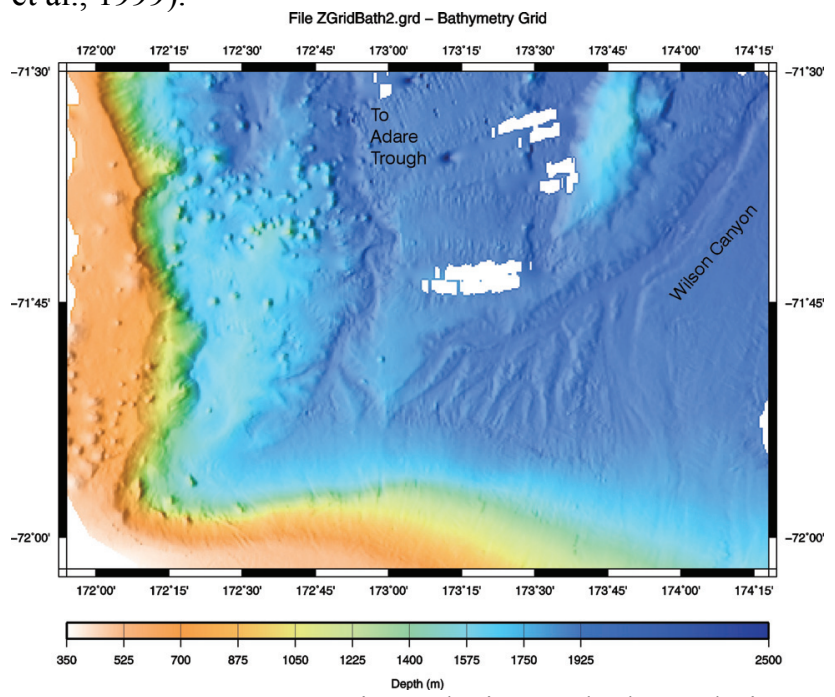

Figure 4. Upper continental rise and slope drainage patterns.

At the base of slope, the channel network funnels newly-formed Antarctic Bottom Water into the Scott and Wilson Canyons, and through the Adare Trough. Seismic data show the effect of the strong seafloor currents along these channels, but a depositional environment further west, with drift sediments resulting from lower velocity contour currents.

Acknowledgments. We appreciate the support of N B Palmer personnel on cruise NBP0209 and NBP0701. We acknowledge the contribution of $\mathrm{P}$ Bart (co-editor) and considered reviews by $\mathrm{J}$ B Anderson and an anonymous reviewer. We gratefully acknowledge financial support from NSF (S S Jacobs), and GNS and NZ GSF (F J Davey).

\section{References}

Anderson, J. B. (1999), Antarctic Marine Geology, Cambridge University Press, Cambridge, U.K., 289 pp.

Baines, P., and S. Condie (1998), Observations and Modeling of Antarctic Downslope Flows: A Review, Ant. Res. Ser. 75, 29-49, Am. Geophy.. Un., Wash. DC.

Barnes, P. W. (1986), Morphological studies of the Wilkes Land continental shelf glacial and iceberg effects, in Eittreim, S.L., Hampton, M.A., eds., The Antarctic continental margin: Geology and geophysics of offshore Wilkes Land: CPCEMR Earth Sciences Series 5A, Houston, Texas, Am. Assoc. Petrol. Geologists, 175-194.

Barnes, P. W. and R. Lien (1988), Icebergs rework shelf sediments to 500 m, off Antarctica, Geology, 16, 1130-1133.

Bart, P. .J. and J. B. Anderson (2000), Relative temporal stability of the Antarctic ice sheets during the late Neogene based on minimum 
frequency of outer shelf grounding events. Earth and Planetary Science Letters, 182, 259-272.

Cande, S. C., J. M. Stock, D. Müller, and T. Ishihara (2000), Cenozoic Motion between East and West Antarctica, Nature, 404, 145-150,.

Davey, F. J. (2004), Ross Sea Bathymetry, 1:2,000,000, version 1.0. Institute of Geological \& Nuclear Sciences geophysical map 16, Institute of Geological \& Nuclear Sciences Ltd, Lower Hutt, N.Z.

Davey, F. J. and S. S. Jacobs (2005), The Morphology of the Ross Sea Shelf and Northwest Margin, abstract in 3rd International Conference on the Oceanography of the Ross Sea Antarctica, 10-14 October 2005, Scuola Grande di San Giovanni Evangelista, Venice, Italy

Dinniman, M. S., J. M. Klinck, and W.O. Smith, Jr. (2003), Cross shelf exchange in a model of the Ross Sea circulation and biogeochemistry. Deep-Sea Res. II, 50, 3103-3120.

Dowdeswell, J. A., J. Evans, C. O'Cofaigh, and J. B. Anderson (2006), Morphology and sedimentary process on the continental slope off Pine Island Bay, Amundsen Sea, West Antarctica, Geological Society of America Bulletin, v. 118, p. 606-619.

Gordon, A.L., E. Zambianchi, A. Orsi, M. Visbeck, C. F. Giulivi, T. Whitworth III, and G. Spezie, (2004), Energetic plumes over the western Ross Sea continental slope, Geophysical Research Letters, 31, L21302, doi:10.1029/2004GL020785

Hayes, D. E., and F. J. Davey (1975), A geophysical study of the Ross Sea, Antarctica, in Hayes, D.E., Frakes, L.A., eds., Initial Reports of the deep Sea Drilling Project, vol 28, US Government Printing Office, Washington, D.C., 887-907.

Houtz, R., and F. J. Davey (1973), Seismic profiler and sonobuoy measurements in the Ross Sea, Antarctica, J. Geophys. Res., 78, 3448-3468.
Jacobs, S. S., and C. F. Giulivi (1999), Thermohaline data and Ocean Circulation of the Ross Sea Continental Shelf, in Spezie, G., Manzella, G.M.R., (eds), Oceanography of the Ross Sea, Antarctica, Springer-Verlag, Italia, Milano, 3-16.

Keys, J. R. (1990), Ice, in, Glasby, G.A., ed., Antarctic Sector of the Pacific, Elsevier Oceanographic Series, 51, New York, pp 95-123.

Keys, J., S. Jacobs, and P. Barnett (1990), The calving and drift of iceberg B-9, Antarctic Science, 2(3), 243-257

Lien, R. (1981), Seabed features in the Blaaenga area, Weddell Sea, Antarctica, in Proceedings, Ports and Engineering under Arctic Conditions, 1981: Quebec, Canada, University of Laval, 2, 706-716

O'Brien P. E., E. M. Truswell, and T. Burton (1994), Morphology and late glacial history of Prydz Bay, Antarctica, based on echo sounder data, in Cooper, A.K., Barker, P.F., Webb, P.N., Brancolini, G., eds., The Antarctic Continental Margin: Geophysical and Geological Stratigraphic Records of Cenozoic Glaciation, Paleoenvironments and Sea Level Change, Terra Antarctica, 1(2), 403-405.

Rignot, E., and S. Jacobs (2002), Rapid bottom melting widespread near Antarctic ice sheet grounding lines, Science, 296, 2020-2023.

Shipp, S., J. B. Anderson, and E. Domack (1999), Late PleistoceneHolocene retreat of the West Antarctic Ice-Sheet system in the Ross Sea: Part 1-Geophysical results, GSA Bulletin, 111(10), 1486-1516.

Wellner, J. S., D. C. Heroy, and J. B. Anderson (2006), The death mask of the Antarctic Ice Sheet: comparison of glacial geomorphic features across the continental shelf: Geomorphology, v. 75, p. 157-171.

Whitworth, T., III, and A. H. Orsi (2006), Antarctic Bottom Water production and export by tides in the Ross Sea, Geophysical Research Letters, 33, L12609, doi:10.1029/2006GL026357. 